\title{
SISTEM PELAYANAN JASA DAN PENJUALAN PRODUK PERCETAKAN BERBASIS WEB PADA PROPOSTER INDONESIA
}

\author{
Elidjen; Gandi Cahyadi; Mario Andika \\ Computer Science Department, School of Computer Science Binus University \\ Jl. K.H. Syahdan No. 9, Palmerah, Jakarta Barat 11480 \\ elidjen@binus.edu
}

\begin{abstract}
Various constraints related to the availability of up-to-date information services and product sales happen to ProPoster Indonesia, a business of digital printing and display services system run since 2002. ProPoster Indonesia needs to offer an easy access to services and online service sales of printing products to its customers and plans to expand its business services throughout Indonesia. These conditions initiate the development of web-based service and products sales system for ProPoster Indonesia. The main objectives are to overcome the difficulties in obtaining the latest information related to services and products and facilitate promotional printing services to all parts of Indonesia. The sequential linear process model is used to develop the overall system while literature study is done to enrich the insight to develop a better system. The user friendly system makes easy for customers to get the latest information that ultimately facilitate the service process and product sales.
\end{abstract}

Keywords: web based-information system, services, sales, printing, linear sequential model

\begin{abstract}
ABSTRAK
Berbagai kendala terkait dengan ketersediaan informasi layanan dan penjualan produk dialami ProPoster Indonesia, suatu usaha jasa digital printing dan display system yang berjalan sejak tahun 2002. ProPoster Indonesia ingin memberikan kemudahan layanan dan jasa penjualan produk secara online kepada para pelanggan serta berencana melakukan ekspansi layanan bisnisnya ke seluruh wilayah Indonesia. Kondisi inilah melatarbelakangi pengembangan sistem pelayanan jasa dan penjualan produk percetakan berbasis web pada Proposter Indonesia. Tujuan utamanya adalah mengatasi kesulitan mendapatkan informasi terkini terkait pelayanan jasa dan produk percetakan serta memudahkan promosi layanan ke seluruh wilayah Indonesia. Sequential linear process model digunakan untuk mengembangkan sistem secara keseluruhan dan studi kepustakaan yang digunakan untuk memperkaya wawasan guna mengembangkan sistem yang lebih baik. Sistem yang user friendly memudahkan pelanggan mendapatkan berbagai informasi terkini yang pada akhirnya memudahkan proses pelayanan jasa dan penjualan produk.
\end{abstract}

Kata kunci: sistem informasi berbasis web, pelayanan, penjualan, percetakan, linear sequential model 


\section{PENDAHULUAN}

ProPoster Indonesia merupakan perusahaan pelayanan jasa digital printing dan display system yang juga menyediakan berbagai produk pendukungnya seperti Roll-up Banner Stands, Electronic Scrolling Banner, Promotion Desk System, Exhibition Backdrop System, Tailor Made Stands, Accessories (Foam, Acrylic, PVC Sheet), dan Floor Stand. ProPoster dengan visinya "To become the most preferred supplier for large format printing and display system" berencana untuk mempeluas cakupan area pelayanannya tidak hanya di Jakarta saja tapi juga di seluruh seluruh Indonesia. Namun, seiring dengan semakin berkembangnya usaha yang dimiliki, ProPoster Indonesia mendapatkan beberapa kendala yang perlu diatasi dan diperlukan untuk meningkatkan pelayanan jasa dan penjualan produk yang diberikan kepada pemakai jasanya guna meningkatkan kinerja sehingga meningkatkan pendapatan perusahaan.

Inisiatif untuk mengatasi beberapa kendala dan upaya untuk meningkatkan pelayanan jasa dan penjualan produk percetakan inilah yang melatarbelakangi dikembangkannya sistem layanan jasa dan penjualan produk percetakan berbasis web pada ProPoster Indonesia.

\section{Tinjauan Pustaka}

\section{Sistem}

Menurut Valacich et al (2004, p.6), sistem adalah sekelompok elemen yang saling berhubungan digunakan untuk fungsi bisnis dengan batasan yang teridentifikasi, yang bekerja sama untuk mencapai beberapa tujuan. Menurut O’Brien \& Marakas (2008, p.24), sekelompok komponen yang saling berhubungan, dengan batasan yang terdefinisi dengan jelas, bekerja sama untuk memperoleh beberapa tujuan tertentu dengan menerima input serta menghasilkan output dalam proses transformasi yang teratur. Dari definisi-definisi tersebut dapat disimpulkan bahwa sistem adalah sekelompok komponen yang saling berhubungan, dengan batasan yang terdefinisi dengan jelas, bekerja sama untuk memperoleh beberapa tujuan tertentu dengan menerima input serta menghasilkan output dalam proses transformasi yang teratur.

\section{Penjualan}

Menurut Weitz, Castleberry, dan Tanner Jr. (2001, p4) Penjualan adalah kegiatan bisnis yang melibatkan proses komunikasi antar orang selama penjual dapat mengerti dan memuaskan kebutuhan pembeli sehingga saling menguntungkan kedua belah pihak. Peter dan Donnelly Jr. (2004, p.129) mendefinisikan penjualan sebagai hubungan timbal balik antara pembeli potensial dan penjual yang memenuhi tiga tugas, yaitu mengidentifikasikan kebutuhan dari pembeli potensial, mencocokkan kebutuhan dengan satu atau lebih barang atau layanan yang dimiliki perusahaan dan menyakinkan pembeli membayar produk atau layanan tersebut. Penjualan merupakan sasaran akhir dari kegiatan pemasaran karena pada bagian ini ada penetapan harga, diadakan perundingan dan perjanjian serah terima barang maupun cara pembayaran yang disepakati oleh kedua belah pihak, sehingga tercapai suatu titik kepuasan.

\section{Internet}

Internet adalah jaringan komputer yang ada di seluruh dunia dimana setiap komputer memiliki alamat (Internet address) yang dapat digunakan untuk mengirim data atau informasi. Dalam hal ini komputer yang dahulunya berdiri sendiri dapat berhubungan langsung dengan host-host atau komputer-komputer yang lainnya. Internet terdiri dari World Wide Web (WWW), Usenet (Electronic bulletin boards), Telnet dan FTP (File Transfer Protocol) (Forrest, 1999, p.16). 
Internet adalah sebuah jaringan komputer yang sangat besar dan terdiri dari jaringan-jaringan kecil yang saling terhubung yang mencakup seluruh dunia (Oetomo, 2001, p.10), Internet merupakan jaringan komputer dunia yang meliputi jutaan komputer. Komputer-komputer tersebut dapat saling bertukar informasi.

\section{Web Server}

Web server adalah suatu program yang menawarkan pelayanan yang bisa diperoleh seluruh jaringan. Web server merupakan suatu tipe server khusus yang dapat berkomunikasi dengan client menggunakan HTTP. Web server menerima permintaan dari client dan merespon-nya, biasanya dengan mengembalikan sebuah dokumen atau gambar (Minoli \& Minoli, 1998, p.33).

\section{Web Browser}

Web browser adalah suatu program yang dirancang untuk mengambil informasi-informasi dari suatu server komputer pada jaringan Internet (Sutarman, 2003, p.7). Web browser adalah piranti lunak yang dijalankan pada komputer pemakai yang meminta informasi dari Web server dengan menampilkannya sesuai dengan file data itu sendiri (Ellsworth \& Ellsworth, 1997, p.4).

\section{Linear Sequential Process Model}

Ada beberapa model proses yang dapat digunakan untuk mengembangkan sistem. Dalam artikel ini dibahas satu model yang digunakan untuk mengembangkan sistem pengiriman barang berbasis web pada ProPoster Indonesia. Linear sequential model disebut juga classic life cycle atau waterfall model dimana model ini menyarankan pendekatan sekuensial linier yang sistematis untuk pengembangan piranti lunak yang dimulai pada tingkatan sistem dengan urutan dari analisis, rancangan, penulisan program, pengujian, dan dukungan.

Model ini meliputi beberapa aktivitas berikut: (1) system/information engineering and modeling - karena piranti lunak selalu merupakan bagian dari suatu sistem yang lebih besar (atau bisnis), pekerjaan dimulai dari menetapkan persyaratan untuk semua elemen sistem dan kemudian mengalokasikan beberapa subset dari persyaratan piranti lunak; (2) software requirement analysis untuk memahami sifat program yang akan dibangun, software engineer harus memahami domain informasi untuk piranti lunak serta fungsi yang diperlukan, perilaku, kinerja, dan antar muka. Persyaratan untuk kedua sistem danpiranti lunak yang didokumentasikan dan di-review dengan pelanggan (customer); (3) design - rancangan piranti lunak sebenarnya adalah sebuah proses bertingkat yang fokus pada empat atribut yang berbeda dan sebuah program, struktur data, arsitektur piranti lunak, representasi piranti lunak, prosedural (algoritma) detil. Proses rancangan menerjemahkan kebutuhan ke representasi dari piranti lunak yang dapat dinilai untuk kualitas sebelum dimulai penulisan program. Seperti persyaratan, rancangan didokumentasi dan menjadi bagian dari konfigurasi piranti lunak.; (4) code generation - rancangan harus diterjemahkan ke dalam bentuk yang dapat dibaca oleh mesin (machine-readable form). Penulisan programlah yang menangani tugas ini; (5) testing - proses pengujian fokus pada logika internal software, memastikan bahwa semua persyaratan sudah diuji, dan pada fungsi eksternal, yaitu melakukan pengujian untuk menemukan kesalahan dan memastikan bahwa input yang didefinisikan akan menghasilkan hasil aktual yang sesuai dengan hasil yang dibutuhkan; (6) support - piranti lunak pasti akan mengalami perubahan setelah digunakan sekian lama. Karena kesalahan telah ditemukan atau karena pelanggan membutuhkan peningkatan fungsional atau kinerja, piranti lunak harus disesuaikan untuk mengakomodasi perubahan dalam lingkungan eksternal (misalnya, perubahan diperlukan karena sistem operasi baru atau peripheral device). Berikut adalah gambar linear sequential model (Gambar 1). 


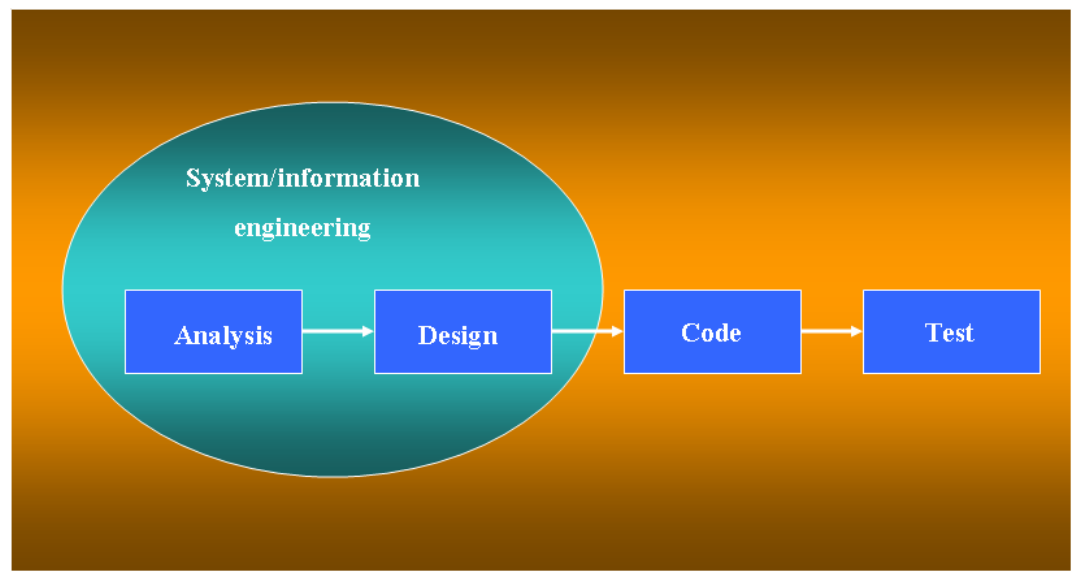

Gambar 1. Linear sequential model (Pressman, 2001, p.29).

\section{Interaksi Manusia dan Komputer}

Interaksi manusia dan komputer adalah ilmu yang berhubungan dengan perancangan, evaluasi dan implementasi sistem komputer interaktif untuk digunakan oleh manusia, serta studi fenomenafenomena besar yang berhubungan dengannya (Shneiderman, 1998, p.8).

Menurut Shneiderman (1998, p74), ada delapan aturan emas (golden rules) yang dapat digunakan sebagai pedoman untuk membuat antar muka yang user friendly, yaitu: (1) rancangan yang dibuat harus konsisten (strive for consistency) - konsistensi ada berbagai macam, seperti konsistensi dalam urutan aksi harus diperhatikan dalam suatu situasi yang memiliki kemiripan. Menu, pesan dan help haruslah menggunakan istilah / terminologi yang sama; (2) memungkinkan pemakai menggunakan shortcuts (enable frequent users to use shortcuts) - seiring dengan meningkatnya penggunaan dari suatu sistem, pengguna menginginkan suatu interaksi yang minimal tapi dengan hasil yang sama dengan interaksi yang lebih banyak. Singkatan, special key, perintah tersembunyi dan makro adalah contoh fasilitas yang sangat dihargai oleh pengguna dengan tingkatan pengguna yang tinggi. Waktu respon yang rendah dan tingkat display yang tinggi, merupakan daya tarik tersendiri bagi para pemakai; (3) memberikan umpan balik yang informatif (offer informative feedback) - untuk setiap sistem diharapkan adanya suatu umpan balik bagi pemakai. Respon yang diberikan tergantung dari aksi yang dilakukan. Respon yang diberikan kepada pengguna hendaknya lebih nyata. Penampilan visual dari suatu objek merupakan suatu cara untuk menampilkan perubahan secara eksplisit; (4) merancang dialog untuk menghasilkan keadaan akhir yang baik (design dialog to yield closure) urutan aksi harus terorganisasi menurut kelompok tertentu yang terdiri dari permulaan, tengah dan akhir. Umpan balik yang informatif kepada pengguna pada taraf akhir dari suatu kelompok aksi akan memberikan kepuasan kepada pengguna bahwa aksi yang mereka lakukan telah berhasil dengan baik, sehingga akan memberikan kesan kepada pengguna bahwa mereka aman untuk melakukan aksi selanjutnya; (5) memberikan penanganan kesalahan yang sederhana (offer simple error handling) perancangan suatu sistem haruslah dibuat sedemikian rupa sehingga pengguna tidak akan menimbulkan kesalahan yang signifikan. Jika pengguna akhirnya melakukan suatu kesalahan, sistem hendaknya memberikan peringatan yang sederhana dan konstruktif serta spesifik; (6) mengizinkan pembalikan aksi (undo) dengan mudah (permit easy reversal of actions) - setiap aksi harus dirancang sedemikian rupa sehingga dapat melakukan pembalikan untuk kembali ke keadaan semula sebelum aksi tersebut dijalankan. Dengan adanya fasilitas ini, pengguna akan memiliki keberanian untuk mengeksploitasikan sistem yang telah dibuat, karena untuk semua kesalahan yang timbul, pengguna memiliki pilihan untuk melakukan pembalikan terhadap aksi yang telah dilakukan; (7) mendukung kontrol-kontrol internal (support internal locus of control) - pengguna yang berpengalaman biasanya memiliki keyakinan bahwa mereka bertanggung jawab terhadap sistem dan sistem akan memberikan 
respon terhadap aksi yang mereka lakukan. Respon yang aneh, urutan yang aneh dalam entry data dan kesulitan dalam memperoleh informasi serta ketidakmampuan untuk mendapatkan hasil sesuai aksi tertentu akan menimbulkan kekecewaan dan keraguan bagi pengguna; (8) mengurangi beban ingatan jangka pendek (reduce short-term memory load) - keterbatasan manusia dalam mengelola memori jangka pendek menyebabkan dibutuhkannya suatu tampilan yang sederhana mungkin, pengaturan dalam multipage, pergerakan window yang sesedikit mungkin, waktu latihan yang cukup dan optimal serta pengaturan dalam urutan aksi. Hal ini juga harus didukung dengan ketersediaan dari adanya akses secara langsung, kode singkatan dan informasi yang dibutuhkan oleh pengguna.

\section{METODE}

Metode yang digunakan dalam pengembangan sistem ini menggunakan linear sequential process model meliputi system/information engineering and modeling, software requirement analysis, design, code generation, testing, dan support. Metode analisis dilakukan dengan mempelajari sistem yang sedang berjalan pada ProPoster Indonesia melalui wawancara kepada beberapa orang pimpinannya. Analisis dilakukan sedemikian rupa untuk memahami permasalahan yang terdapat pada sistem yang sedang berjalan sehingga didapatkan solusi yang tepat. Dari solusi tersebut dibuatlah rancangan sistem pelayanan jasa dan penjualan produk percetakan berbasis web. Studi kepustakaan dilakukan dengan membaca berbagai literatur untuk meningkatkan pemahaman mengenai berbagai teori yang dibutuhkan dari membuat rancangan hingga melakukan evaluasi serta menyimpulkan hasil evaluasi.

\section{HASIL DAN PEMBAHASAN}

ProPoster Indonesia melakukan penawaran produk atau jasa kepada kepada langganannya melalui brosur sedangkan promosi kepada calon pelanggan biasanya dilakukan dengan melalui kegiatan pameran, seminar, dan demo/presentasi produk. Pelanggan yang membutuhkan layanan jasa dan ingin membeli produk percetakan datang langsung ke ProPoster Indoensia atau melakukan pemesanan melalui telepon. Pelanggan memesan pelayanan jasa percetakan dengan menyertakan informasi terkait jumlah, jenis jasa atau produk yang diinginkan. Sales menerima pesanan pelanggan dan memberikan perincian biaya atas pesanan tersebut. Negosiasi harga dimungkinkan oleh ProPoster Indonesia. Setelah terjadi kesepakatan harga dan ketentuan terkait pesanan tersebut, pelanggan perlu memberikan rancangan awal berupa file gambar yang disimpan ke dalam media penyimpanan digital (biasa berupa CD). Proof print (contoh/sample desain visual yang telah dicetak dalam ukuran kecil) akan diberikan kepada pelanggan untuk diperiksa. Apabila pelanggan menyetujui prof print tersebut, bagian produksi akan melakukan pencetakan. Apabila proof print belum disetujui, bagian produksi akan melakukan revisi terhadap proof print tersebut dan dikirim kembali ke pelanggan sampai disetujui oleh pelanggan dan setelah itu bagian produksi akan melakukan pencetakan dan bagian finishing \& installation akan melakukan sentuhan akhir pada hasil cetak tersebut misalnya laminasi, percobaan instalasi pada display system, ataupun pengepakan.

\section{Permasalahan yang Dihadapi}

Setelah melakukan wawancara dengan pimpinan ProPoster Indonesia dan pembagian kuesioner kepada 16 pelanggan ProPoster Indonesia dan melakukan analisis terhadap sistem yang sedang berjalan ditemukanlah beberapa masalah berikut; (1) $44 \%$ pelanggan menyatakan bahwa mereka mengalami kesulitan untuk mendapatkan informasi terkini terkait pelayanan jasa dan penjualan produk percetakan; (2) 81\% pelanggan menyatakan bahwa mereka terkendala dengan waktu 
yang harus dihabiskan untuk datang ke ProPoster Indonesia untuk mendapatkan layanan jasa dan penjualan produk percetakan sementara $62 \%$ pelanggan sudah terbiasa melakukan transaksi pembelian secara online melalui Internet dan $81 \%$ pelanggan menginginkan layanan pemesanan jasa dan pembelian produk secara online melalui Internet; (3) pelanggan dari luar area Jakarta relatif sulit mendapatkan informasi produk karena informasi produk kurang disebarkan ke luar Jakarta karena pertimbangan biaya promosi yang cukup besar untuk area di luar Jakarta.

\section{Pemecahan Masalah}

Seiring dengan kemajuan yang dicapai oleh ProPoster Indonesia serta keinginan untuk mengurangi berbagai kendala yang terjadi dengan pelayanan dan penjualan yang dilakukan dengan sistem yang berjalan, maka solusinya adalah merancang sebuah sistem pelayanan jasa dan penjualan produk percetakan berbasis web. Berikut adalah gambaran sistem yang dibuat dan gambaran menu utama (Gambar 2-4).

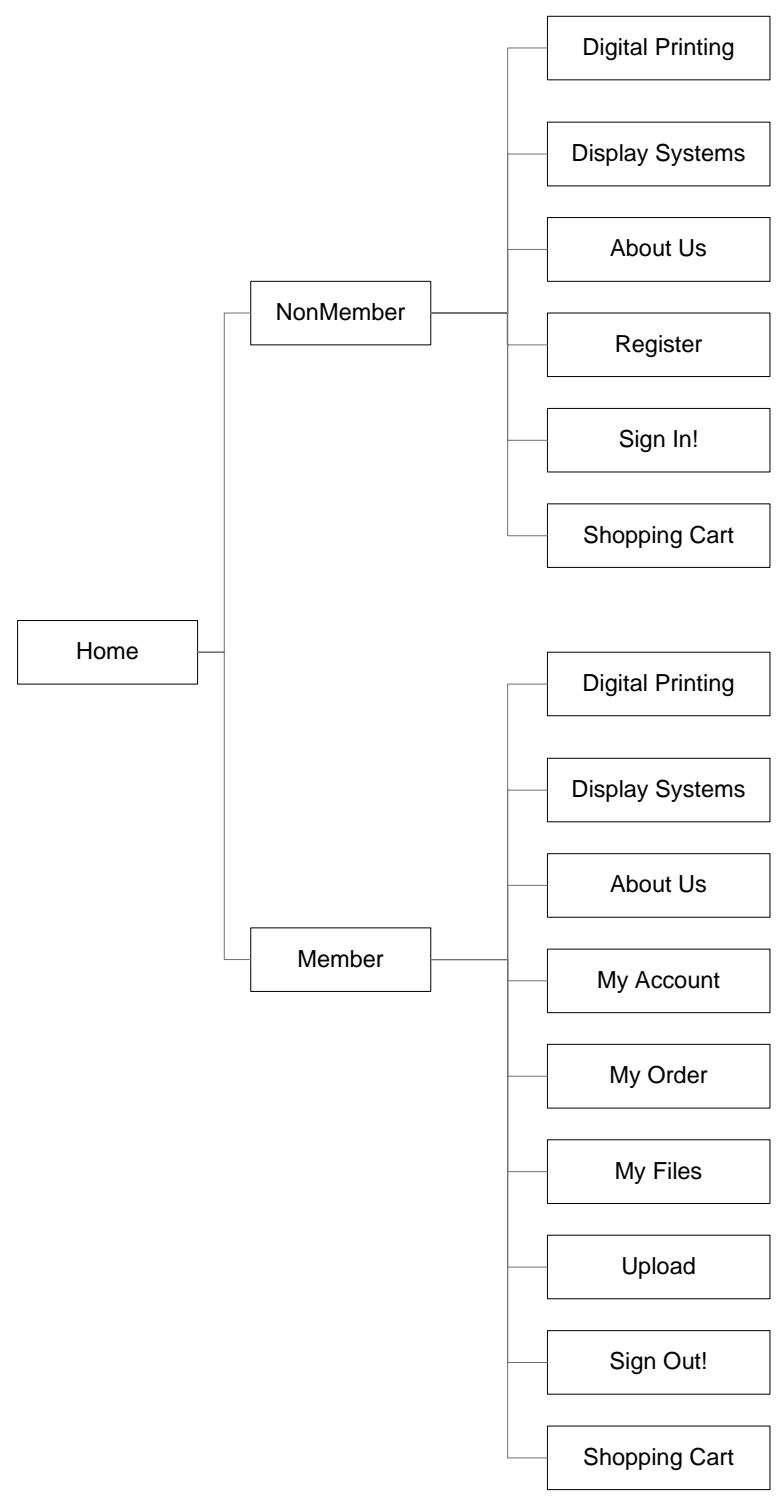

Gambar2. Struktur menu member dan nonmember. 


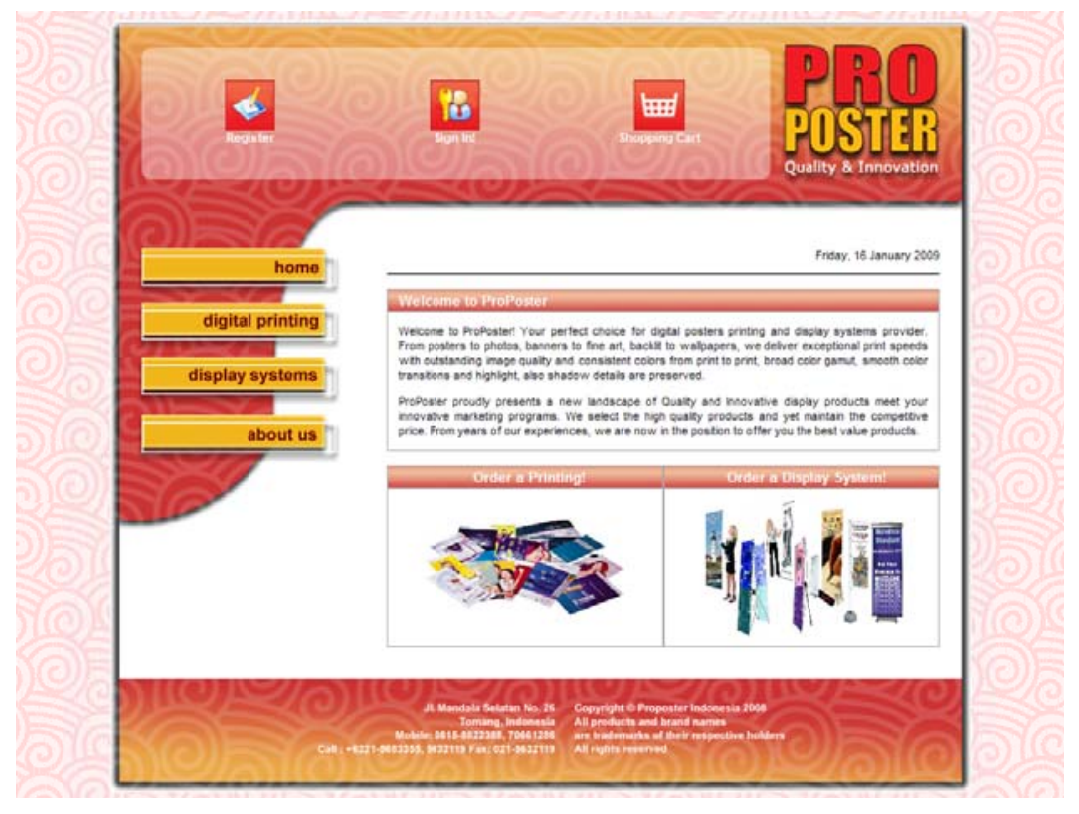

Gambar 3. Halaman utama nonmember.

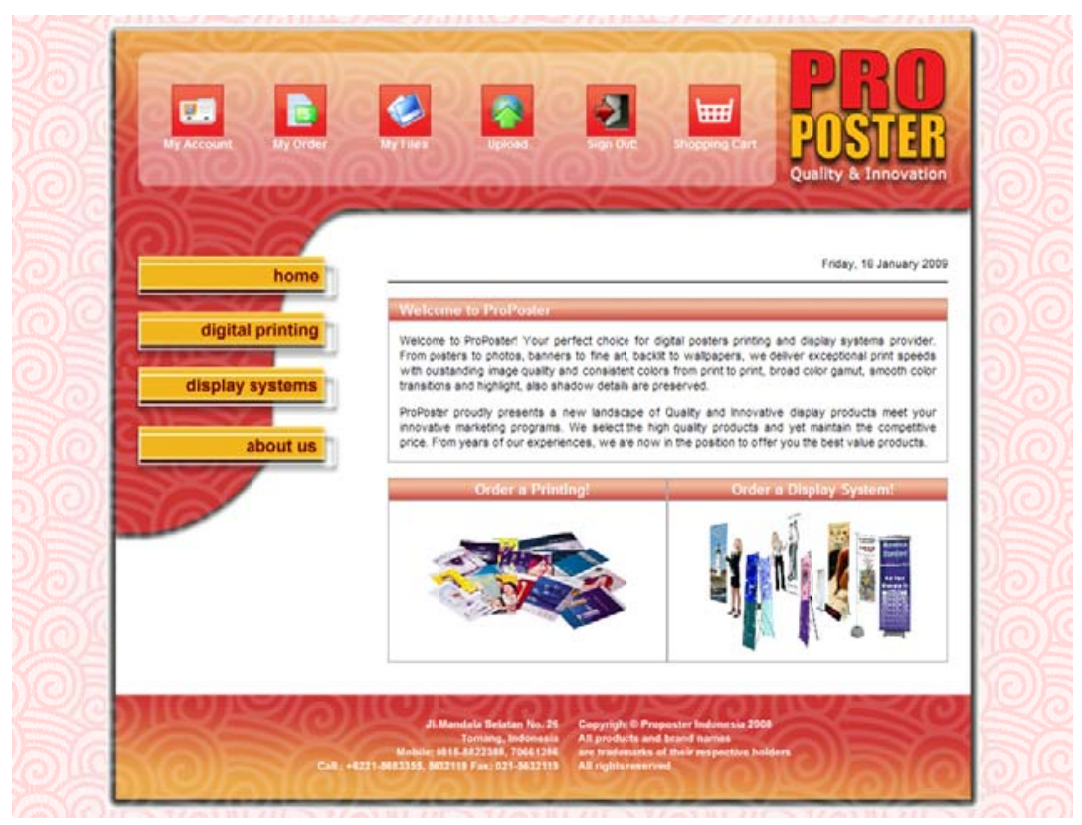

Gambar 4. Halaman utama member.

\section{Evaluasi}

Evaluasi sistem dilakukan dengan mengevaluasi hasil pengisian kuesioner yang dilakukan oleh tiga belas pelanggan pelayanan jasa dan penjualan produk percetakan pada ProPoster Indonesia dan wawancara yang dilakukan kepada Chief Marketing Officere ProPoster Indonesia setelah mereka menggunakan sistem yang telah dikembangkan. Evaluasi yang telah dilakukan menunjukkan bahwa sistem mudah digunakan dan berbagai informasi terkini yang dibutuhkan mudah didapatkan dan lengkap. Sistem juga dievaluasi untuk menjamin dipenuhinya delapan aturan emas guna menghasilkan 
antar muka yang baik. Hasil evaluasi menunjukkan sistem yang dibuat sudah mengacu kepada delapan aturan emas tersebut dan antar muka yang dihasilkan user friendly.

\section{PENUTUP}

Sistem user friendly yang dikembangkan pada ProPoster Indonesia memudahkan pelanggan baik di area Jakarta maupun di area lainnya di Indonesia mendapatkan informasi terkini mengenai pelayanan jasa dan produk percetakan dan juga mempermudah pelanggan melakukan pemesanan pelayanan jasa dan produk percetakan secara efektif dan efisien. Dengan berbagai keterbatasan dalam dalam pengembangan sistem penjualan berbasis web ini, terdapat beberapa saran yang dapat dipertimbangkan untuk pengembangan sistem ini lebih lanjut. Sistem penjualan berbasis web ini perlu dikembangkan lebih lanjut seiring dengan aktivitas pemesanan yang bertambah dan pemintaan design yang lebih kompleks dari pelanggan. Penambahan fitur seperti memberikan testimoni. Sistem ini belum menggunakan fitur-fitur seperti memberikan testimoni, sehingga disarankan untuk pengembang berikutnya dapat menambahkan fitur ini sebagai salah satu bentuk layanan tambahan kepada pelanggan.

\section{DAFTAR PUSTAKA}

Ellsworth, Jill H., Matthew V. Ellsworth. (1997). Pemasaran di Internet, (edisi revisi). (Yulianto, terj.). Jakarta: Grasindo.

Forrest, Edward. (1999). Internet Marketing Research: Resources and Techniques. Sydney: McGraw Hill Australia.

Minoli, Daniel \& Minoli, Emma. (1998). Web Commerce Technology Handbook. New York: McGraw-Hill.

O’Brien, J. A. \& Marakas, G. M. (2008). Management Information Systems, (edisi ke-8). New York: McGraw-Hill.

Oetomo, Budi S. D. (2001). Perspektif e-Business: Tinjauan Teknis, Manajerial dan Strategi. Yogyakarta: Andi.

Peter, Paul J., Donnelly Jr., James H. (2004). Marketing Mangement: Knowledge and Skills, (7th ed.). New York: McGraw-Hill.

Pressman, Roger S. (2001). Software Engineering: A Practitioner's Approach, (5 ${ }^{\text {th }}$ ed.). New-York: McGraw-Hill.

Sutarman. (2003). Membangun Aplikasi Web dengan PHP dan MySQL. Yogyakarta: Graha Ilmu.

Valacich, J. S., George, J. F. \& Hoffer, J. A. (2004). Essentials of Systems Analysis and Design, (2 ${ }^{\text {nd }}$ ed.). New Jersey: Pearson Prentice Hall.

Weitz, Barton A., Castleberry, Stephen B., Tanner Jr., John F. (2001). Selling: Building Partnerships, ( $4^{\text {th }}$ ed.). New York: McGraw-Hill. 